\title{
Systemic Treatment of Gastroenteropancreatic Neuroendocrine Carcinoma
}

Kazhan Mollazadegan, $M D^{*}$ Staffan Welin, MD, PhD Joakim Crona, MD, PhD

\section{Address}

*Department of Medical Sciences, Uppsala University, Akademiska Sjukhuset ing 100, 75185, Uppsala, Sweden

Email: Kazhan.mollazadegan@medsci.uu.se

Email: Joakim.crona@medsci.uu.se

Published online: 10 June 2021

(C) The Author(s) 2021

This article is part of the Topical Collection on Neuroendocrine Cancers

Keywords Systemic treatment · Extra pulmonary $\cdot$ Poorly differentiated $\cdot$ High-grade $\cdot$ Gastroenteropancreatic carcinoma

\section{Opinion statement}

Treatment recommendations for advanced gastroenteropancreatic neuroendocrine carcinomas (GEP-NEC) are based on uncontrolled, mainly retrospective data. Chemotherapy can offer palliative relief, but long-lasting complete responses or cures are rare. The European Neuroendocrine Tumour Society (ENETS) and European Society for Medical Oncology (ESMO) recommend platinum-based chemotherapy as first-line treatment. This has been the golden standard since the late 1980s and has been evaluated in mostly retrospective clinical studies. However, progression is inevitable for most patients. Unfortunately, data on effective second-line treatment options are scant, and ENETS and ESMO recommendations propose fluorouracil- or temozolomide-based chemotherapy schedules. As such, there is a huge unmet need for improved care. Improved knowledge on GEP-NEC biology may provide a pathway towards more effective interventions including chemotherapy, targeted gene therapy, peptide receptor radionuclide therapy, as well as immune checkpoint inhibitors. The review summarises this current state of the art as well as the most promising developments for systemic therapy in GEP-NEC patients. 


\section{Introduction}

Gastroenteropancreatic neuroendocrine carcinomas (GEP-NECs) are highly aggressive cancers associated with poor prognosis and fast disease progression. The incidence of this group of diseases is thought to have increased over the last 3-4 decades and is now reported to be about 7 per 100,000 persons/year [1-6]. The classification has evolved throughout the years based on better understanding of disease biology as well as improved diagnostic tools. Since 2017, the World Health Organization (WHO) classifications $[7,8]$ recognise poorly differentiated high-grade NEC as a distinct entity from high-grade neuroendocrine tumours (NET) [9]. This is now reflected in treatment recommendations where first-line platinum-based chemotherapy is reserved for NECs and not for high-grade NETs [10, 11]. Despite this improved understanding of NECs, available systemic therapies are considered to provide only palliative relief, and recommendations are mostly supported by uncontrolled, retrospective studies $[12 \bullet \bullet, 13]$. New therapies are emerging, with both immune checkpoint inhibitors and genetic-guided therapy having shown some interesting results. One promising example is treatment with anti-BRAF therapy in colorectal NEC displaying oncogenic BRAF mutations [14, 15].

In this review article, we aim to provide an overview of the current recommendations for systemic therapy in GEP-NEC. Based on a comprehensive review of biomedical and clinical trials databases, we present the evidence underlying available recommendations, with focus on first-line and second-line scenarios. Finally, we aim to review the current state of the art and research directions that can improve treatment options for this high-risk patient group.

\section{Classification of neuroendocrine neoplasms}

The classification and terminology of gastroenteropancreatic neuroendocrine neoplasms (GEP-NENs) have been revised and changed throughout history. The original classification for these diseases was based on embryological origin and recognised foregut, midgut, and hindgut variants [16, 17]. In 2000, a new classification was presented by the WHO that recognised well-differentiated and poorly differentiated endocrine carcinoma based on their distinct biological characteristics and clinical outcomes [18]. A decade later, demand for improved prognostic and diagnostic criteria led to the WHO 2010 classification [8] based on the Ki-67 proliferation index, mitotic index, and tumour cell morphology. This also introduced the term ' $\mathrm{NEN}^{\prime}$ as an umbrella term for well and poorly differentiated tumours of neuroendocrine cell origin [19].

According to the $2010 \mathrm{WHO}$ grading and classification [20], GEP-NENs are separated into well-differentiated NET of low or intermediate grade, with a Ki67 value of $<3 \%$ and $3-20 \%$, respectively, and high-grade poorly differentiated NEC grade (G) 3 with Ki-67 $>20 \%$. GEP-NEC G3 is further divided histopathologically into large-cell or small-cell NEC [20-22]. In 2017, the grading and classification system was updated for pancreatic NENs and introduced the category of well-differentiated high-grade NET G3 with Ki- $67 \geq 20 \%$. Since 2019, this is accepted for all gastrointestinal NENs [8].

Further categorisation of NEC can be made according to disease site, and the most important distinction is pulmonary or extrapulmonary NEC. Extrapulmonary NECs occur most commonly in the gastrointestinal tract but can also be found in the urinary bladder, cervix, and prostate [2]. GEP-NECs display high proliferation rates and are associated with a poor prognosis, even when diagnosed without metastases [23]. Most GEP-NEC patients present with 
distant metastases, and this disease state is considered to be incurable. For GEPNEC patients that did not receive any treatment, survival has been reported to be as short as 1 month, while those patients that had received chemotherapy had a median survival of 12-19 months in various studies [9, 24].

\section{Biology of neuroendocrine neoplasms}

The genetic landscape of GEP-NEC is incompletely characterised, but it is clear that mutations in TP53, KRAS, PIK3CA/PTEN, or BRAF play an important role in malignant transformation and progression (reviewed in $[25,26]$ ). Girardi et al. [27] performed a systematic review on this topic and identified 33 relevant studies. Microsatellite instability was found in about $10 \%$ of gastric and colorectal NECs. Additionally, an impaired mismatch repair pathway has been observed in 93\% (30/32) of colorectal NECs [28]. Chalmers et al. [29] were able to describe tumour mutational burden using targeted comprehensive genetic profiling of 100,000 human cancer genomes across 100 tumour types. NECs were also analysed in this study, and in 140 gastrointestinal NECs, the median tumour mutational burden was 3.7 , and $4.3 \%$ had at least 20 mutations per megabase. Among 233 pancreatic NECs, the median tumour mutational burden was 2.7 , and $1.7 \%$ of patients had at least 20 mutations per megabase. The results from the study indicated that high tumour mutational burden may correlate with a better response to immunotherapy.

Girardi et al. also showed how alterations in TP53 gene and p53 protein was found to occur in most, if not all, GEP-NECs. Other common alterations were observed to involve the MAPK/ERK, p16/Rb/cyclin D1, and Hedgehog and Notch signalling pathways, with somatic alterations commonly observed in KRAS, BRAF, RB1, or BCL2. Furthermore, small-cell and large-cell NECs have been associated with different molecular signatures. Small-cell NEC-like tumours were characterised by the bi-allelic inactivation of both TP53 and RB1 $[30,31]$, whereas the genomics of large-cell NEC were more complex and heterogeneous having a 'carcinoma-like' signature, with similar profiles to those observed in carcinomas without neuroendocrine differentiation occurring in the corresponding location [30,31].

\section{Current treatment strategies}

Current ENETS (2016) [13] and ESMO (2020) guidelines [12••] for management of GEP-NECs take note of the extent and resectability of the disease as well as its proliferative activity to guide treatment decisions. The staging system for adenocarcinomas [32] should be used, and patients with localised disease can be considered for surgical resection followed by adjuvant chemotherapy. Highrisk features such as large tumour size and advanced disease constitute contraindications for surgery. Instead, those patients should be considered for systemic therapy to provide palliative relief. Patients with NEC are thought to benefit from having their cases assessed by a multidisciplinary conference with experience of the disease group. However, it should not delay the initial patient management as early treatment onset is thought to be crucial to avoid rapid patient deterioration. 
Platinum-based chemotherapy using cisplatin/etoposide or carboplatin/ etoposide is recommended as first-line therapy for advanced NEC in both ENETS and ESMO guidelines $[12 \bullet \bullet, 13]$. The standard administration route is by intravenous infusion, though oral etoposide was recently reported to have equivalent efficacy and also reduced hospital stay from 3 days to 1 [33].

The concept of platinum-based chemotherapy for treatment of NEC originated from the experience in small-cell lung cancer which shares many biological characteristics with NEC [34]. In 1991, Moertel et al. [10] reported on fortyfive patients with metastatic NET that received cisplatin/etoposide. Among 18 patients with 'anaplastic NEC', nine had partial response (PR), three had complete response (CR), and the median duration of response was 8 months. However, in 27 patients with well-differentiated morphology, the response rate (RR) was only 7\%. This was validated by Mitry et al. [11] who studied response to cisplatin/etoposide in 53 patients with 'NETs' (according to the 1980s Gould and Warren classifications [35,36]). Twelve patients had well-differentiated and 41 had poorly differentiated tumours. The RR among poorly differentiated cases was $41 \%$, while only $8 \%$ of well-differentiated tumours had a response. While these two studies established that poorly differentiated NENs can be sensitive to platinum-based chemotherapy, prognosis remained poor with less than $20 \%$ of patients surviving longer than 2 years. This experience has been validated in multiple clinical studies: 14 of them are reviewed in Table 1 including 5 prospective and 9 retrospective trials. In summary, RR ranged from 14 to $67 \%$, and overall survival (OS) remained poor between 6 and 22 months [10,11,24,37-49].

In addition to well-differentiated morphology, a lower Ki-67 index has also been associated with a lower efficacy in terms of RR. In the NORDIC NEC study [9], patients with NEC G3 (WHO 2010) who received first-line platinum-based chemotherapy were reported to have a $31 \%$ RR to first-line chemotherapy. Patients with Ki-67 below 55\% were found to have a worse RR compared to those with a Ki- $67 \geq 55 \%$ ( $15 \%$ versus $42 \%$ ). The relationship between tumour response to Ki-67 index and morphology was further validated in a retrospective study from eight European centres [24] that assessed the effect of carboplatin/etoposide in patients with NET G3 $(n=37)$ and NEC $(n=167)$. Disease control rate (DCR) and progression-free survival (PFS) were found to be significantly higher in NEC in comparison to NET G3, whereas OS was shown to be significantly longer in NET G3 (99 versus 17 months). Additional biomarkers for response to platinum-based chemotherapy have been evaluated. A multicentre retrospective study [31] investigated a population of 70 patients with pancreatic NENs G3 that had received platinum-based chemotherapy and correlated outcomes to clinicopathological and molecular features. Patients with $R B$ loss or KRAS mutation showed a high RR, $80 \%$ and $77 \%$, respectively. In the patients with pancreatic NET G3, there were no tumours with $R B$ loss or KRAS mutation, and the RR were $24 \%$ and $23 \%$, respectively. This suggests it may be valuable to use these immunohistochemical and genetic markers in future pancreatic NEC classifications.

Randomised studies comparing alternatives to cisplatin/etoposide are lacking with one exception. In a randomised phase II study [46], the efficacy of cisplatin/etoposide was compared to cisplatin/irinotecan for the first-line 
Table 1. Efficacy of platinum-based chemotherapy for neuroendocrine carcinoma

\begin{tabular}{|c|c|c|c|c|c|c|}
\hline Reference & Study design & $\begin{array}{l}\text { NEC study } \\
\text { population, } n \\
\text { patients }\end{array}$ & Intervention & ORR & $\begin{array}{l}\text { Median } \\
\text { PFS, } \\
\text { months }\end{array}$ & $\begin{array}{l}\text { Median } \\
\text { OS, } \\
\text { months }\end{array}$ \\
\hline $\begin{array}{l}\text { Moertel } \\
\text { et al. } \\
1991 \\
{[10]}\end{array}$ & $\begin{array}{l}\text { Prospective, } \\
\text { observational }\end{array}$ & 18 anaplastic NEC & Cisplatin/etoposide & $67 \%$ & 8 & 19 \\
\hline $\begin{array}{l}\text { Hainsworth } \\
\text { et al. } \\
2006 \\
\text { [43] }\end{array}$ & $\begin{array}{l}\text { Prospective, phase } \\
\text { II, single arm }\end{array}$ & $\begin{array}{l}15 \\
\text { extrapulmonary } \\
\text { poorly } \\
\text { differentiated } \\
\text { NEC }\end{array}$ & $\begin{array}{l}\text { Carboplatin/etoposide } \\
\quad+\text { paclitaxel }\end{array}$ & $53 \%$ & 8 & 15 \\
\hline $\begin{array}{l}\text { Li et al. } \\
2017 \\
\text { [44] }\end{array}$ & $\begin{array}{l}\text { Prospective, phase } \\
\text { II, Single arm, } \\
\text { open label }\end{array}$ & 40 GEP-NEC & $\begin{array}{l}\text { Cisplatin/irinotecan + } \\
\text { octreotide LAR }\end{array}$ & NA & 6 & 13 \\
\hline $\begin{array}{l}\text { Walter et al. } \\
\text { 2017 } \\
\text { [45] }\end{array}$ & Prospective cohort & 202 GEP-NEC & $\begin{array}{l}\text { Carboplatin/etoposide } \\
\text { or } \\
\text { cisplatin/etoposide }\end{array}$ & $50 \%$ & 6 & 12 \\
\hline $\begin{array}{l}\text { Zhang et al. } \\
2020 \\
{[46]}\end{array}$ & $\begin{array}{l}\text { Prospective, phase } \\
\text { II, randomised }\end{array}$ & 66 GEP-NEC & $\begin{array}{l}\text { Cisplatin/etoposide } \\
\text { versus } \\
\text { cisplatin/irinotecan }\end{array}$ & $42 \%$ & $\begin{array}{l}6 \text { (EP) } \\
6 \text { (IP) }\end{array}$ & $\begin{array}{l}11 \text { (EP) } \\
10 \text { (IP) }\end{array}$ \\
\hline $\begin{array}{l}\text { Mitry et al. } \\
1999 \\
{[11]}\end{array}$ & Retrospective & 41 PD-NEC & Cisplatin/etoposide & $42 \%$ & 9 & 15 \\
\hline $\begin{array}{l}\text { Iwasa et al. } \\
\text { 2010 } \\
\text { [41] }\end{array}$ & Retrospective & 21 GEP-NEC & Cisplatin/etoposide & $14 \%$ & 2 & 6 \\
\hline $\begin{array}{l}\text { Okita et al. } \\
2011 \\
{[40]}\end{array}$ & Retrospective & 22 gastric-NEC & Cisplatin/irinotecan & $75 \%$ & 7 & 22 \\
\hline $\begin{array}{l}\text { Nakano } \\
\text { et al. } \\
2012 \\
{[48]}\end{array}$ & Retrospective & $\begin{array}{l}44 \\
\quad \text { extrapulmonary } \\
\text { poorly } \\
\text { differentiated } \\
\text { NEC }\end{array}$ & Cisplatin/irinotecan & $64 \%$ & 7 & 16 \\
\hline $\begin{array}{l}\text { Yamaguchi } \\
\text { et al. } \\
2014 \\
\text { [37] }\end{array}$ & Retrospective & 206 GEP-NEC & $\begin{array}{l}160 \\
\text { cisplatin/irinotecan } \\
46 \text { cisplatin/etoposide }\end{array}$ & $\begin{array}{l}50 \% \\
\text { (IP) } \\
28 \% \\
(E P)\end{array}$ & $\begin{array}{l}5 \text { (IP) } \\
4 \text { (EP) }\end{array}$ & $\begin{array}{l}13 \text { (IP) } \\
7 \text { (EP) }\end{array}$ \\
\hline $\begin{array}{l}\text { Heetfeld } \\
\text { et al. } \\
2015 \\
\text { [24] }\end{array}$ & Retrospective & 113 GEP-NEC & Platinum/etoposide & $35 \%$ & 5 & 16 \\
\hline $\begin{array}{l}\text { Imai et al. } \\
2016 \\
{[38]}\end{array}$ & Retrospective & 19 GEP-NEC & Carboplatin/etoposide & $47 \%$ & 7 & 13 \\
\hline $\begin{array}{l}\text { Raj et al. } \\
2017 \\
{[39]}\end{array}$ & Retrospective & 25 PD-NEC & Platinum agents & $37 \%$ & NA & 10 \\
\hline
\end{tabular}


Table 1. (Continued)

\begin{tabular}{|c|c|c|c|c|c|c|}
\hline Reference & Study design & $\begin{array}{l}\text { NEC study } \\
\text { population, } n \\
\text { patients }\end{array}$ & Intervention & ORR & $\begin{array}{l}\text { Median } \\
\text { PFS, } \\
\text { months }\end{array}$ & $\begin{array}{l}\text { Median } \\
\text { OS, } \\
\text { months }\end{array}$ \\
\hline $\begin{array}{l}\text { Brandi et al. } \\
2018 \\
\text { [42] }\end{array}$ & Retrospective & $\begin{array}{l}21 \text { GEP-NEC and } \\
\text { CUP-NEC }\end{array}$ & Platinum/etoposide & $52 \%$ & 7 & 16 \\
\hline
\end{tabular}

therapy in patients with advanced GEP-NEC. Sixty-six patients were randomised to either cisplatin/etoposide or cisplatin/irinotecan. Primary endpoint was objective response rate (ORR), and the study was powered to detect a $30 \% \mathrm{RR}$ in the cisplatin/etoposide arm and 50\% RR in the experimental cisplatin/irinotecan arm. This primary endpoint was not met as ORR was $42.4 \%$ in both study arms. In the cisplatin/etoposide arm, median PFS was 6.4 months and median OS was 11.3, with similar outcomes in the cisplatin/ irinotecan arm, 5.8 months for PFS and 10.2 months for OS, respectively. One encouraging note is that there are several ongoing clinical trials studying different strategies for first-line therapy for GEP-NEC patients (Table 2). We wish to highlight a phase II study investigating the efficacy of a platinum agent in combination with anti-programmed death 1 (PD-1) antibody (NCT03980925) and a phase II study analysing 177Lu-DOTATATE plus anti PD-1 antibody (NCT04525638), in patients where at least one tumour lesion should have expression of somatostatin receptors confirmed by PET. Other ongoing studies include a phase II study examining platinum-agents plus everolimus (NCT02695459), and two ongoing randomised phase II studies comparing the efficacy of platinum agents to capecitabine/temozolomide (NCT02595424), as well as modified FOLFIRINOX (folinic acid, fluorouracil, irinotecan and oxaliplatin) (NCT04325425).

There is currently no consensus regarding optimal therapeutic strategy after firstline therapy in advanced GEP-NEC patients [13]. As a consequence, patients have received heterogeneous treatment regimens (Table 3). Second-line treatments that are recommended by ESMO and ENETS $[12 \bullet \bullet, 13]$ include fluorouracil-based chemotherapy in combination with either irinotecan or oxaliplatin as well as temozolomide in monotherapy or in combination with capecitabine.

In a retrospective study from 2011 [50], efficacy of temozolomide-based chemotherapy in second-line/third-line was studied among 25 patients with poorly differentiated endocrine carcinoma (WHO 2000). Ki-67 index ranged from $>20$ to $90 \%$, and tumours were mostly of gastrointestinal origin. Median PFS was 6 months and median OS was 22 months. The study also found that non-responders to first-line chemotherapy, with a Ki-67 below $60 \%$ and uptake on somatostatin receptor scintigraphy, had a better response to temozolomidebased chemotherapy. Temozolomide monotherapy was further examined in 
Table 2. Randomised clinical trials currently recruiting patients with neuroendocrine carcinoma

\begin{tabular}{|c|c|c|c|c|}
\hline $\begin{array}{l}\text { Study } \\
\text { abbreviation }\end{array}$ & $\begin{array}{l}\text { ClinicalTrials. } \\
\text { gov reference }\end{array}$ & Trial design & Intervention(s) & $\begin{array}{l}\text { Primary } \\
\text { endpoint }\end{array}$ \\
\hline NIPINEC & NCT03591731 & $\begin{array}{l}\text { Phase II, } \\
\text { randomised }\end{array}$ & $\begin{array}{l}\text { Arm A: nivolumab } \\
\text { Arm B: nivolumab/ipilimumab }\end{array}$ & ORR \\
\hline FOLFIRINEC & NCT04325425 & $\begin{array}{l}\text { Phase II, } \\
\text { randomised }\end{array}$ & $\begin{array}{l}\text { Experimental: modified } \\
\text { FOLFIRINOX } \\
\text { Comparator: platinum/etoposide }\end{array}$ & Median PFS \\
\hline SENECA & NCT03387592 & $\begin{array}{l}\text { Phase II, } \\
\text { randomised }\end{array}$ & $\begin{array}{l}\text { Experimental: capecitabine and } \\
\text { temozolomide } \\
\text { Comparator: FOLFIRI }\end{array}$ & $\begin{array}{l}\text { 1: DCR } \\
\text { 2: treatment related } \\
\text { adverse events }\end{array}$ \\
\hline BEVANEC & NCT02820857 & $\begin{array}{l}\text { Phase II, } \\
\text { randomised }\end{array}$ & $\begin{array}{l}\text { Experimental: FOLFIRI/ } \\
\text { bevacizumab } \\
\text { Comparator: FOLFIRI }\end{array}$ & $\begin{array}{l}\text { Proportion of } \\
\text { patients alive }\end{array}$ \\
\hline NET02 & NCT03837977 & $\begin{array}{l}\text { Phase II, } \\
\text { randomised }\end{array}$ & $\begin{array}{l}\text { Arm A: liposomal irinotecan, } \\
\text { fluorouracil, folinic acid } \\
\text { Arm B: docetaxel }\end{array}$ & PFS \\
\hline NA & NCT02687958 & $\begin{array}{l}\text { Phase II, } \\
\text { randomised }\end{array}$ & $\begin{array}{l}\text { Experimental: everolimus } \\
\text { Non-intervention: observational }\end{array}$ & PFS \\
\hline NA & NCT02595424 & $\begin{array}{l}\text { Phase II, } \\
\text { randomised }\end{array}$ & $\begin{array}{l}\text { Experimental: capecitabine + } \\
\text { temozolomide } \\
\text { Comparator: cisplatin/etoposide } \\
\text { or carboplatin/etoposide }\end{array}$ & PFS \\
\hline
\end{tabular}

the second- or third-line setting in 28 NEC patients [51]. Seven had pancreatic NEC and showed a median OS of 7.0 months versus 21 patients with nonpancreatic NEC that had a median OS of 2.9 months. Median PFS was 3.3 months versus 1.9 months, respectively. Only 16 were evaluable for radiological response and DCR was 38\%, while no PR or CR were observed. Efficacy of temozolomide plus capecitabine was further assessed [52] in patients with GEP-NET G3 $(n=20)$ and GEP-NEC G3 $(n=12)$. DCR was $70 \%$ in the NET group and $30 \%$ in NEC group. Median PFS was 15.3 months for NET G3 and 3.3 months for NEC G3, whereas median OS was 22 months and 4.6 months, respectively.

Fluorouracil-based chemotherapy regimens have also been investigated. Hentic et al. [53] reported in a retrospective study the efficacy of the FOLFIRI regimen (folinic acid, fluorouracil, and irinotecan) among 39 patients with gastrointestinal NEC. Only 19 patients completed the treatment course, the rest could not follow through due to toxicity or death. The median OS among these 19 patients was 18 months and median PFS 4.0 months.

Du et al. [49] studied the efficacy of FOLFIRI in 11 patients with gastrointestinal-NEC, the median PFS was 6.5, and the median OS was 13.0 months. Furthermore, a single-centre retrospective study from 2015 analysed the antitumour efficacy of FOLFOX (folinic acid, fluorouracil, and oxaliplatin) among 20 patients with NEC after progression on platinum-based regimens. 
Table 3. Studies on second- and third-line therapies for neuroendocrine carcinoma

\begin{tabular}{|c|c|c|c|c|c|c|}
\hline Reference & Study design & $\begin{array}{l}\text { NEC study } \\
\text { population, } n \\
\text { patients }\end{array}$ & Intervention & ORR & $\begin{array}{l}\text { Median } \\
\text { PFS, } \\
\text { months }\end{array}$ & $\begin{array}{l}\text { Median } \\
\text { OS, } \\
\text { months }\end{array}$ \\
\hline $\begin{array}{l}\text { Chen et al. } \\
2020 \\
\text { [55] }\end{array}$ & $\begin{array}{l}\text { Open-Label, } \\
\text { multicentre, } \\
\text { phase II, } \\
\text { single arm } \\
\text { study }\end{array}$ & $\begin{array}{l}22 \text { GEP-NEC, } \\
2^{\text {nd }} \text {-line }\end{array}$ & TLC388 & $0 \%$ & 2 & 4 \\
\hline $\begin{array}{l}\text { Welin et al. } \\
\text { 2011 } \\
\text { [50] }\end{array}$ & $\begin{array}{l}\text { Retrospective, } \\
\text { observational }\end{array}$ & $\begin{array}{l}25 \text { poorly } \\
\text { differentiated } \\
\text { endocrine } \\
\text { carcinoma, } \\
2^{\text {nd }} \text {-line }\end{array}$ & $\begin{array}{l}\text { Temozolomide, +/- } \\
\text { capecitabine, +/- } \\
\text { bevacizumab }\end{array}$ & $33 \%$ & 6 & 22 \\
\hline $\begin{array}{l}\text { Hentic } \\
\text { et al. } \\
2012 \\
\text { [53] }\end{array}$ & Retrospective & $19 \mathrm{NEC}, 2^{\text {nd }}$-line & FOLFIRI & $31 \%$ & 4 & 18 \\
\hline $\begin{array}{l}\text { Olsen et al. } \\
2012 \\
\text { [51] }\end{array}$ & Retrospective & $\begin{array}{l}28 \text { GEP-NEC, } \\
2^{\text {nd }} / 3^{\text {rd }} \text {-line }\end{array}$ & Temozolomide & $38 \%$ & 2 & 4 \\
\hline $\begin{array}{l}\text { Du et al. } \\
2013 \\
\text { [49] }\end{array}$ & Retrospective & $11 \mathrm{GI}-\mathrm{NEC}, 1^{\text {st }}$-line & FOLFIRI & $64 \%$ & 7 & 13 \\
\hline $\begin{array}{l}\text { Ando et al. } \\
\text { 2015 } \\
\text { [59] }\end{array}$ & $\begin{array}{l}\text { Retrospective, } \\
\text { observational }\end{array}$ & $\begin{array}{l}10 \text { GEP-NEC, } \\
2^{\text {nd }} \text {-line }\end{array}$ & Amrubicin & $20 \%$ & 3 & 5 \\
\hline $\begin{array}{l}\text { Nio et al. } \\
2015 \\
{[57]}\end{array}$ & $\begin{array}{l}\text { Retrospective, } \\
\text { observational }\end{array}$ & $\begin{array}{l}13 \text { GEP-NEC, } \\
2^{\text {nd }} \text {-line }\end{array}$ & Amrubicin & $40 \%$ & 4 & 7 \\
\hline $\begin{array}{l}\text { Hadoux } \\
\text { et al. } \\
2015 \\
{[54]}\end{array}$ & $\begin{array}{l}\text { Retrospective, } \\
\text { observational }\end{array}$ & $\begin{array}{c}12 \text { GEP-NEC, } 8 \\
\text { other NEC, } \\
2^{\text {nd }} / 3^{\text {rd }} \text {-line }\end{array}$ & FOLFOX & NA & 5 & 10 \\
\hline $\begin{array}{l}\text { Apostilidis } \\
\text { et al. } \\
2016 \\
{[56]}\end{array}$ & $\begin{array}{l}\text { Retrospective, } \\
\text { observational }\end{array}$ & $\begin{array}{l}30 \\
\text { extrapulmonary } \\
\text { poorly } \\
\text { differentiated } \\
\mathrm{NEC}, 2^{\text {nd }} \text {-line }\end{array}$ & Topotecan & NA & 2 & 4 \\
\hline $\begin{array}{l}\text { Araki et al. } \\
2016 \\
\text { [58] }\end{array}$ & Retrospective & $\begin{array}{l}18 \\
\text { extrapulmonary } \\
\text { PD-NEC, } \\
\text { GI-NEC, } \\
1^{\text {st }} / 2^{\text {nd }} \text {-line }\end{array}$ & Amrubicin & $19 \%$ & 4 & 8 \\
\hline $\begin{array}{l}\text { Rogowski } \\
\text { et al. } \\
2019 \\
{[52]}\end{array}$ & Retrospective & $12 \mathrm{NEC}, 2^{\text {nd }}$-line & Temozolomide/capecitabine & NA & 3 & 5 \\
\hline
\end{tabular}


Table 3. (Continued)

\begin{tabular}{|c|c|c|c|c|c|c|}
\hline Reference & Study design & $\begin{array}{l}\text { NEC study } \\
\text { population, } n \\
\text { patients }\end{array}$ & Intervention & ORR & $\begin{array}{l}\text { Median } \\
\text { PFS, } \\
\text { months }\end{array}$ & $\begin{array}{l}\text { Median } \\
\text { OS, } \\
\text { months }\end{array}$ \\
\hline $\begin{array}{l}\text { Sugiyama } \\
\text { et al. } \\
2020 \\
\text { [90] }\end{array}$ & $\begin{array}{l}\text { Retrospective, } \\
\text { observational }\end{array}$ & 5 GI-NEC, $2^{\text {nd }}$-line & FOLFIRI & $40 \%$ & 6 & 11 \\
\hline
\end{tabular}

The median follow-up was 19 months and median PFS was 4.5 months. Among the 17 evaluable patients, 5 PR (29\%), 6 stable diseases (SD) (35\%), and 6 progressive diseases (PD) (35\%) were observed. Median OS was 9.9 months [54]. In the study by Heetfeld et al. [24], the effects of second- ( $n=79)$ and third-line ( $n=39$ ) FOLFIRI or FOLFOX among patients with NEC were also studied. Median PFS for second-line was 3.0 months and median OS 7.0 months, for third-line median PFS, and median OS was 2.5 and 6.2 months.

Topoisomerase inhibitors were traditionally considered an alternative treatment strategy in small-cell lung cancer and was therefore subject to one prospective [55] and four retrospective [56-59] studies in NEC patients. Median PFS was about 2-4 months with a median OS of between 4 and 7 months and a RR between 19 and $40 \%$. This class of drugs is currently not recommended in neither ENETS nor ESMO guidelines.

\section{Future treatment strategies}

Numerous agents have been investigated for treatment of NEC throughout the years, supported either by a biological rationale or efficacy in other relevant diseases. Encouragingly, the current clinical trial pipeline also shows a high activity. Here we have focused on three different classes of drugs believed to provide promising new alternatives: 177Lu-DOTATATE, immunotherapy, and anti-BRAF treatment.

A study published in 2018 analysed the treatment outcomes after 177LuDOTATATE in patients with a GEP-NEN having a high Ki-67 index [60]. Thirtythree patients with advanced GEP-NENs (Ki-67 15-70\%) displaying adequate uptake on somatostatin receptor imaging received treatment with $177 \mathrm{Lu}-$ DOTATATE, $6 \%$ achieved PR, while 64\% showed SD. The median PFS was 23 months, and the median OS was 52.9 months. Twenty-three patients had Ki-67 $<35 \%$ and a median PFS of 26.3 months, while 10 patients had Ki-67 >35\% and a median PFS of only 6.8 months. A few more studies show almost similar outcomes with RR of about $42 \%$ in subgroup analyses for GEP-NENs with Ki$67 \geq 55 \%$ [61-63]. As previously mentioned, Lu177-DOTATATE plus nivolumab is now subject to a phase II study in the first-line setting (NCT04525638). 
Translational studies demonstrated a rationale for immunotherapy in GEPNECs by displaying a different microenvironment compared with welldifferentiated GEP-NETs [64]. NECs commonly showed presence of cell surface receptor PD-1, programmed death-ligand 1, and/or tumour-infiltrating lymphocytes (TILs), which were also poor prognostic factors [65-68]. At the same time, immunotherapeutic agents were approved for diseases with similar biology to NEC including avelumab for treatment of Merkel cell carcinoma [6971], as well as durvalumab and atezolizumab for treatment of small-cell lung cancer [72-75]. Based on the results from a phase I/II, non-randomised and randomised multicentre trial, nivolumab has been FDA approved as third-line monotherapy for metastatic SCLC [76].

In a controlled, phase III trial, patients with extensive stage small-cell lung cancer were randomised to carboplatin/etoposide with either atezolizumab or placebo. Hazard ratio for death was favouring the combination therapy, 0.70 (95\% confidence interval 0.54-0.91) [73]. This established a rationale for combining chemotherapy and immunotherapy using checkpoint inhibitors also in NEC.

Recent studies reporting on the efficacy of immunotherapy in NEC patients include two phase II studies performed by Vijayvergia et al. on pembrolizumab in 29 patients with NEN G3 [77•]. Of these, $19(66 \%)$ had poorly differentiated NEC and nine (34\%) had well-differentiated NET. Twenty-eight (97\%) had prior platinum-based chemotherapy. There was one (3.4\%) PR and six (20.7\%) SD, and 17 (58.6\%) had PD. Median OS was 20.4 weeks. While ten tumour samples (67\%) stained positive for PD-1 and eight tumour samples (53\%) had infiltrating TILs, these biomarkers were not correlated with DCR. In a second phase II study [78], avelumab was studied in 29 patients with advanced GEPNECs. Interim analysis after 8 weeks showed a DCR of 32\% (4 SD, 2 PR). In responders, mean duration of disease control was $20( \pm 13.8)$ weeks, with 4 patients showing SD or PR $\geq 6$ months. Median OS was 4.2 months.

Patel et al. [79] reported data from a phase II basket trial of anti-CTLA-4 and anti-PD-1 antibodies with results on non-pancreatic NENs presented separately. Thirty-two patients were included and 18 (56\%) were high-grade NEN. One patient (3\%) had CR and seven (22\%) had PR. All responses were observed in the NEC cohort, with ORR of 44\% for high-grade NEC (WHO 2010). Similarly, Klein et al. [80] reported data from a subgroup of advanced NENs included in the CA209-538 clinical trial on ipilimumab and nivolumab. There were 29 patients included, of which 13 (45\%) had high-grade tumours. Seven patients had PR and the ORR was $24 \%$. Objective responses were achieved in seven intermediate and high-grade tumours, two were NEC.

While combination immunotherapy is considered a promising new treatment strategy for NEC, monotherapy with either anti PD-1 or anti PD-L1 antibodies appears to be less favourable. In a phase II, multicentre, single-arm study, the efficacy of spartalizumab was studied in metastatic well-differentiated NETs $(n=95)$ and poorly differentiated GEP-NECs $(n=21)$. The ORRs were $7.4 \%$ in the NET group and $4.8 \%$ in the GEP-NEC group. Patients with PD-L1 expressions of more than $1 \%$ or presenting with more than $1 \%$ of $\mathrm{CD} 8+$ cells at baseline were observed to have higher ORR. The primary endpoint was not met [81]. Clarifying results from clinical trials are awaited (Table 2) concerning the efficacy of immunotherapy in NEC patients. 
Finally, anti-BRAF therapy has shown to be efficient across different cancers harbouring BRAF V600E mutations [82-85]. However, some diseases, most notably colorectal cancer, have not shown a high level of responsiveness to such drugs $[85,86]$. The results from three separate studies revealed that $22 \%(39 / 174)$ of colorectal NECs harboured a BRAF V600E alteration [87, 88, 89•]. In their translational study, Capdevila et al. reported that BRAF V600E mutant colon NEC may benefit from $B R A F$ inhibition in monotherapy and that EGFR status is essential to predict innate sensitivity and acquired resistance by a differential methylation of its gene regulatory regions [89•]. While these are promising predinical data, the field still awaits clarifying results, whether anti-BRAF therapy could provide relief to patients with BRAF V600E mutated colon NECs. Klempner [87] described two patients with colorectal NEC treated with dabrafenib (BRAF inhibitor) and trametinib (MEK inhibitor). Both achieved PR that were ongoing at 7 and 9 months, respectively. Burkart [14] presented two cases with colorectal NEC, patient one was treated with dabrafenib and trametinib and achieved PR, lasting for 5 months, whereas the second patient who received dabrafenib and pazopanib (broad tyrosine kinase inhibitor) had achieved disease stabilisation, with progression after 6 months. Finally, in a basket trial including various cancers harbouring oncogenic $B R A F$ mutations receiving vemurafenib, two patients with NEC were described. One had a PR lasting 4 months and the second had SD of unknown duration [15].

\section{Summary}

A majority of the studies underlying current treatment recommendations for GEPNECs have a retrospective and observational design and examined small patient populations. Based on the available data, ESMO and ENETS guidelines $[12 \bullet \bullet, 13]$ recommend platinum-based chemotherapy for patients with advanced GEP-NEC. For second-line treatment, the guidelines recommend fluorouracil- or temozolomide-based chemotherapy. The increased awareness of the molecular heterogeneity of these tumours might suggest that it will be more beneficial for future treatment regimens to be individualised and profiled towards biomarkers. There is an urgent need for larger prospective clinical trials of comparative nature, looking at new promising chemotherapeutic and immunotherapeutic regimens as well as targeted gene therapy.

\section{Funding}

Open access funding provided by Uppsala University. JC received funding from the Cancerfonden and Göran Gustafssons stiftelse.

\section{Compliance with Ethical Standards}

\section{Conflict of Interest}

KM declares no conflicts of interest. JC received lecture honoraria from Novartis and IPSEN as well as educational honoraria from NET Connect (funded by IPSEN). 
Human and Animal rights and Informed consent

This article does not contain any studies with human or animal subjects performed by any of the authors.

\section{Open Access}

This article is licensed under a Creative Commons Attribution 4.0 International License, which permits use, sharing, adaptation, distribution and reproduction in any medium or format, as long as you give appropriate credit to the original author(s) and the source, provide a link to the Creative Commons licence, and indicate if changes were made. The images or other third party material in this article are included in the article's Creative Commons licence, unless indicated otherwise in a credit line to the material. If material is not included in the article's Creative Commons licence and your intended use is not permitted by statutory regulation or exceeds the permitted use, you will need to obtain permission directly from the copyright holder. To view a copy of this licence, visit http://creativecommons.org/licenses/by/4.0/.

\section{References and Recommended Reading}

Papers of particular interest, published recently, have been highlighted as:

- Of importance

$\bullet \quad$ Of major importance

1. Hauso O, Gustafsson BI, Kidd M, Waldum HL, Drozdov I, Chan AKC, et al. Neuroendocrine tumor epidemiology: contrasting Norway and North America. Cancer. 2008.

2. Garcia-Carbonero R, Capdevila J, Crespo-Herrero G, Díaz-Pérez JA, Martínez del Prado MP, Alonso Orduña $\mathrm{V}$, et al. Incidence, patterns of care and prognostic factors for outcome of gastroenteropancreatic neuroendocrine tumors (GEP-NETs): Results from the National Cancer Registry of Spain (RGETNE). Ann Oncol. 2010.

3. Sackstein PE, O'Neil DS, Neugut AI, Chabot J, Fojo T. Epidemiologic trends in neuroendocrine tumors: an examination of incidence rates and survival of specific patient subgroups over the past 20 years. Semin Oncol. 2018.

4. Fraenkel M, Kim M, Faggiano A, De Herder WW, Valk GD. Incidence of gastroenteropancreatic neuroendocrine tumours: a systematic review of the literature. Endocr Relat Cancer. 2014.

5. Cetinkaya RB, Aagnes B, Thiis-Evensen E, Tretli S, Bergestuen DS, Hansen S. Trends in incidence of neuroendocrine neoplasms in Norway: a report of 16,075 cases from 1993 through 2010. Neuroendocrinology. 2016.

6. Dasari A, Shen C, Halperin D, Zhao B, Zhou S, Xu Y, et al. Trends in the incidence, prevalence, and survival outcomes in patients with neuroendocrine tumors in the United States. JAMA Oncol. 2017.

7. Lloyd RV, Osamura RY, Klöppel G RJ. WHO classification of tumours of endocrine organs. Fourth Edition - WHO - OMS -. WHO Classification of Tumours of Endocrine Glands. 4th ed. Lyon: IARC; 2017.

8. Nagtegaal ID, Odze RD, Klimstra D, Paradis V, Rugge $\mathrm{M}$, Schirmacher $\mathrm{P}$, et al. WHO classification of tumours of the digestive system. Histopathology. 2019;2020.

9. Sorbye H, Welin S, Langer SW, Vestermark LW, Holt N, Osterlund $\mathrm{P}$, et al. Predictive and prognostic factors for treatment and survival in 305 patients with advanced gastrointestinal neuroendocrine carcinoma (WHO G3): The NORDIC NEC study. Ann Oncol. 2013.

10. Moertel CG, Kvols LK, O'Connell MJ, Rubin J. Treatment of neuroendocrine carcinomas with combined etoposide and cisplatin. Cancer: Evidence of major therapeutic activity in the anaplastic variants of these neoplasms; 1991.

11. Mitry E, Baudin E, Ducreux M, Sabourin JC, Rufié P, Aparicio T, et al. Treatment of poorly differentiated neuroendocrine tumours with etoposide and cisplatin. Br J Cancer. 1999.

12.• Pavel M, Öberg K, Falconi M, Krenning EP, Sundin A, Perren A, et al. Gastroenteropancreatic neuroendocrine neoplasms: ESMO clinical practice guidelines for diagnosis, treatment and follow-up. Ann Oncol. 2020;

Latest treatment guidelines for patients with GEP-NEC.

13. Garcia-Carbonero R, Sorbye H, Baudin E, Raymond E, Wiedenmann B, Niederle B, et al. ENETS consensus guidelines for high-grade gastroenteropancreatic neuroendocrine tumors and neuroendocrine carcinomas. In: Neuroendocrinology; 2016.

14. Burkart J, Owen D, Shah MH, SRZA-M, Roychowdhury $\mathrm{S}$, Wesolowski R, et al. Targeting BRAF mutations in high-grade neuroendocrine carcinoma of the colon. JNCCN J Natl Compr Cancer Netw. 2018.

15. Subbiah V, Puzanov I, Blay JY, Chau I, Lockhart AC, Raje NS, et al. Pan-cancer efficacy of vemurafenib in brafv600-mutant non-melanoma cancers. Cancer Discov. 2020.

16. Williams ED, Sandler M. The Classification of Carcinoid Tumours. Lancet; 1963.

17. Creutzfeldt W. Carcinoid tumors: Development of our knowledge. In: World Journal of Surgery; 1996. 
18. Solcia E, Klöppel G, Sobin LH. Histological typing of endocrine tumours. Histological Typing of Endocrine Tumours; 2000 .

19. Klöppel G. Classification and pathology of gastroenteropancreatic neuroendocrine neoplasms. Endocr Relat Cancer. 2011.

20. Bosman F, Carneiro F, Hruban R, Theise N. WHO classification of tumours of the digestive system. Fourth ed. Lyon: International Agency for research on canser; 2010.

21. Walenkamp AME, Sonke GS, Sleijfer DT. Clinical and therapeutic aspects of extrapulmonary small cell carcinoma. Cancer Treat Rev. 2009.

22. Strosberg J, Nasir A, Coppola D, Wick M, Kvols L. Correlation between grade and prognosis in metastatic gastroenteropancreatic neuroendocrine tumors. Hum Pathol. 2009.

23. Sorbye H, Strosberg J, Baudin E, Klimstra DS, Yao JC. Gastroenteropancreatic high-grade neuroendocrine carcinoma. Cancer. 2014.

24. Heetfeld M, Chougnet CN, Olsen IH, Rinke A, Borbath I, Crespo G, et al. Characteristics and treatment of patients with G3 gastroenteropancreatic neuroendocrine neoplasms. Endocr Relat Cancer. 2015.

25. Mafficini A, Scarpa A. Genetics and epigenetics of gastroenteropancreatic neuroendocrine neoplasms. Endocr Rev. 2019.

26. McNamara MG, Scoazec JY, Walter T. Extrapulmonary poorly differentiated NECs, including molecular and immune aspects. Endocr Relat Cancer. 2020.

27. Girardi DM, Silva ACB, Rêgo JFM, Coudry RA, Riechelmann RP. Unraveling molecular pathways of poorly differentiated neuroendocrine carcinomas of the gastroenteropancreatic system: A systematic review. Cancer Treat Rev. 2017.

28. Olevian DC, Nikiforova MN, Chiosea S, Sun W, Bahary $\mathrm{N}$, Kuan SF, et al. Colorectal poorly differentiated neuroendocrine carcinomas frequently exhibit BRAF mutations and are associated with poor overall survival. Hum Pathol. 2016.

29. Chalmers ZR, Connelly CF, Fabrizio D, Gay L, Ali SM, Ennis R, et al. Analysis of 100,000 human cancer genomes reveals the landscape of tumor mutational burden. Genome Med. 2017.

30. Yachida S, Vakiani E, White CM, Zhong Y, Saunders T, Morgan R, et al. Small cell and large cell neuroendocrine carcinomas of the pancreas are genetically similar and distinct from well-differentiated pancreatic neuroendocrine tumors. Am J Surg Pathol. 2012.

31. Hijioka S, Hosoda W, Matsuo K, Ueno M, Furukawa M, Yoshitomi $\mathrm{H}$, et al. Rb loss and KRAS mutation are predictors of the response to platinum-based chemotherapy in pancreatic neuroendocrine neoplasm with grade 3: A Japanese multicenter pancreatic NEN-G3 study. Clin Cancer Res. 2017.

32. Brierley J, Gospodarowicz MD, Wittekind CT. TNM Classification of Malignant Tumors International Union Against Cancer. 8th. Oxford, England: Wiley;
2017. Oesphagus including oesophagogastric junction. Wiley; 2017

33. Frizziero M, Spada F, Lamarca A, Kordatou Z, Barriuso J, Nuttall C, et al. Carboplatin in Combination with Oral or Intravenous Etoposide for Extra-Pulmonary, Poorly-Differentiated Neuroendocrine Carcinomas. Neuroendocrinology. 2019.

34. Evans WK, Shepherd FA, Feld R, Osoba D, Dang P, Deboer G. VP-16 and cisplatin as first-line therapy for small-cell lung cancer. J Clin Oncol. 1985.

35. Gould VE, Linnoila RIMV, WW. Neuroendocrine cells and neuroendocrine neoplasms of the lung. Pathol Annu. 1983;18:287-330.

36. Warren WHFL, GV. Neuroendocrine neoplams of the lung: a clinicopathologic update. J Thorac Cardiovasc Surg. 1989;98:321-32.

37. Yamaguchi T, Machida N, Morizane C, Kasuga A, Takahashi H, Sudo K, et al. Multicenter retrospective analysis of systemic chemotherapy for advanced neuroendocrine carcinoma of the digestive system. Cancer Sci. 2014.

38. Imai H, Shirota H, Okita A, Komine K, Saijo K, Takahashi M, et al. Efficacy and safety of carboplatin and etoposide combination chemotherapy for extrapulmonary neuroendocrine carcinoma: a retrospective case series. Chemotherapy. 2016.

39. Raj N, Valentino E, Capanu M, Tang LH, Basturk O, Untch BR, et al. Treatment response and outcomes of grade 3 pancreatic neuroendocrine neoplasms based on morphology: well differentiated versus poorly differentiated. Pancreas. 2017.

40. Okita NT, Kato K, Takahari D, Hirashima Y, Nakajima TE, Matsubara J, et al. Neuroendocrine tumors of the stomach: Chemotherapy with cisplatin plus irinotecan is effective for gastric poorly-differentiated neuroendocrine carcinoma. Gastric Cancer. 2011.

41. Iwasa S, Morizane C, Okusaka T, Ueno H, Ikeda M, Kondo S, et al. Cisplatin and etoposide as first-line chemotherapy for poorly differentiated neuroendocrine carcinoma of the hepatobiliary tract and pancreas. Jpn J Clin Oncol. 2010.

42. Brandi G, Paragona M, Campana D, Brighi N, Bondi A, Pantaleo MA, et al. Good performance of platinumbased chemotherapy for high-grade gastroenteropancreatic and unknown primary neuroendocrine neoplasms. J Chemother. 2018.

43. Hainsworth JD, Spigel DR, Litchy S, Anthony GF. Phase II trial of paclitaxel, carboplatin, and etoposide in advanced poorly differentiated neuroendocrine carcinoma: a minnie pearl cancer research network study. J Clin Oncol. 2006.

44. Li J, Lu M, Lu Z, Li Z, Liu Y, Yang L, et al. Irinotecan plus cisplatin followed by octreotide longacting release maintenance treatment in advanced gastroenteropancreatic neuroendocrine carcinoma: IPO-NEC study. Oncotarget. 2017.

45. Walter T, Tougeron D, Baudin E, Le Malicot K, Lecomte T, Malka D, et al. Poorly differentiated gastro-enteropancreatic neuroendocrine carcinomas: are they really 
heterogeneous? Insights from the FFCD-GTE national cohort. Eur J Cancer. 2017.

46. Zhang P, Li J, Li J, Zhang X, Zhou J, Wang X, et al. Etoposide and cisplatin versus irinotecan and cisplatin as the first-line therapy for patients with advanced, poorly differentiated gastroenteropancreatic neuroendocrine carcinoma: a randomized phase 2 study. Cancer. 2020 .

47. Fjällskog MLH, Granberg DPK, Welin SLV, Eriksson C, Öberg KE, Janson ET, et al. Treatment with cisplatin and etoposide in patients with neuroendocrine tumors. Cancer. 2001.

48. Nakano K, Takahashi S, Yuasa T, Nishimura N, Mishima Y, Sakajiri S, et al. Feasibility and efficacy of combined cisplatin and irinotecan chemotherapy for poorly differentiated neuroendocrine carcinomas. Jpn J Clin Oncol. 2012.

49. Du Z, Wang Y, Zhou Y, Wen F, Li Q. First-line irinotecan combined with 5-fluorouracil and leucovorin for high-grade metastatic gastrointestinal neuroendocrine carcinoma. Tumori. 2013.

50. Welin S, Sorbye H, Sebjornsen S, Knappskog S, Busch C, Öberg K. Clinical effect of temozolomide-based chemotherapy in poorly differentiated endocrine carcinoma after progression on first-line chemotherapy. Cancer. 2011.

51. Olsen IH, Sorensen JB, Federspiel B, Kjaer A, Hansen $\mathrm{CP}$, Knigge $U$, et al. Temozolomide as second or third line treatment of patients with neuroendocrine carcinomas. Sci World J. 2012.

52. Rogowski W, Wachuła E, Gorzelak A, Lebiedzińska A, Sulżyc-Bielicka V, Iżycka-Świeszewska E, et al. Capecitabine and temozolomide combination for treatment of high-grade, well-differentiated neuroendocrine tumour and poorly-differentiated neuroendocrine carcinoma - retrospective analysis. Endokrynol Pol. 2019

53. Hentic O, Hammel P, Couvelard A, Rebours V, Zappa $M$, Palazzo $M$, et al. FOLFIRI regimen: an effective second-line chemotherapy after failure of etoposideplatinum combination in patients with neuroendocrine carcinomas grade 3. Endocr Relat Cancer. 2012.

54. Hadoux J, Malka D, Planchard D, Scoazec JY, Caramella C, Guigay J, et al. Post-first-line FOLFOX chemotherapy for grade 3 neuroendocrine carcinoma. Endocr Relat Cancer. 2015.

55. Chen M, Chou W, Hsiao C, Jiang SS, Tsai H, Liu Y, et al. An open-label, single-arm, two-stage, multicenter, phase ii study to evaluate the efficacy of tlc388 and genomic analysis for poorly differentiated neuroendocrine carcinomas. Oncologist. 2020.

56. Apostolidis L, Bergmann F, Jäger D, Winkler EC. Efficacy of topotecan in pretreated metastatic poorly differentiated extrapulmonary neuroendocrine carcinoma. Cancer Med. 2016.

57. Nio K, Arita S, Isobe T, Kusaba H, Kohashi K, Kajitani T, et al. Amrubicin monotherapy for patients with extrapulmonary neuroendocrine carcinoma after platinum-based chemotherapy. Cancer Chemother Pharmacol. 2015.
58. Araki T, Takashima A, Hamaguchi T, Honma Y, Iwasa $\mathrm{S}$, Okita N, et al. Amrubicin in patients with platinumrefractory metastatic neuroendocrine carcinoma and mixed adenoneuroendocrine carcinoma of the gastrointestinal tract. Anti-Cancer Drugs. 2016.

59. Ando T, Hosokawa A, Yoshita H, Ueda A, Kajiura S, Mihara $\mathrm{H}$, et al. Amrubicin monotherapy for patients with platinum-refractory gastroenteropancreatic neuroendocrine carcinoma. Gastroenterol Res Pract. 2015.

60. Nicolini S, Severi S, Ianniello A, Sansovini M, Ambrosetti A, Bongiovanni A, et al. Investigation of receptor radionuclide therapy with 177Lu-DOTATATE in patients with GEP-NEN and a high Ki-67 proliferation index. Eur J Nucl Med Mol Imaging. 2018.

61. Carlsen EA, Fazio N, Granberg D, Grozinsky-Glasberg S, Ahmadzadehfar H, Grana CM, et al. Peptide receptor radionuclide therapy in gastroenteropancreatic NEN G3: a multicenter cohort study. Endocr Relat Cancer. 2019.

62. Zhang J, Kulkarni HR, Singh A, Niepsch K, Müller D, Baum RP. Peptide receptor radionuclide therapy in grade 3 neuroendocrine neoplasms: safety and survival analysis in 69 patients. J Nucl Med. 2019.

63. Thang SP, Lung MS, Kong G, Hofman MS, Callahan J, Michael M, et al. Peptide receptor radionuclide therapy (PRRT) in European Neuroendocrine Tumour Society (ENETS) grade 3 (G3) neuroendocrine neoplasia (NEN) - a single-institution retrospective analysis. Eur J Nucl Med Mol Imaging. 2018.

64. Zhang WH, Wang WQ, Gao HL, Yu XJ, Liu L. The tumor immune microenvironment in gastroenteropancreatic neuroendocrine neoplasms. Biochimica et Biophysica Acta - Reviews on Cancer. 2019.

65. Ferrata M, Schad A, Zimmer S, Musholt TJ, Bahr K, Kuenzel J, et al. PD-L1 expression and immune cell infiltration in gastroenteropancreatic (GEP) and nonGEP neuroendocrine neoplasms with high proliferative activity. Front Oncol. 2019.

66. Schultheis AM, Scheel AH, Ozretić L, George J, Thomas RK, Hagemann T, et al. PD-L1 expression in small cell neuroendocrine carcinomas. Eur J Cancer. 2015.

67. Cavalcanti E, Armentano R, Valentini AM, Chieppa M, Caruso ML. Role of PD-L1 expression as a biomarker for GEP neuroendocrine neoplasm grading. Cell Death Dis. 2017.

68. Kim ST, Ha SY, Lee S, Ahn S, Lee J, Park SH, et al. The impact of PD-L1 expression in patients with metastatic GEP-NETs. J Cancer. 2016.

69. Kaufman HL, Russell J, Hamid O, Bhatia S, Terheyden $\mathrm{P}, \mathrm{D}^{\prime}$ Angelo SP, et al. Avelumab in patients with chemotherapy-refractory metastatic Merkel cell carcinoma: a multicentre, single-group, open-label, phase 2 trial. Lancet Oncol. 2016.

Walker JW, Lebbé C, Grignani G, Nathan P, Dirix L, Fenig E, et al. Efficacy and safety of avelumab treatment in patients with metastatic Merkel cell carcinoma: Experience from a global expanded access program. Journal for ImmunoTherapy of Cancer. 2020. 
71. Kaufman HL, Russell JS, Hamid O, Bhatia S, Terheyden P, D'Angelo SP, et al. Updated efficacy of avelumab in patients with previously treated metastatic Merkel cell carcinoma after $\geq 1$ year of follow-up: JAVELIN Merkel 200, a phase 2 clinical trial. J Immunother Cancer. 2018.

72. Wang S, Zimmermann S, Parikh K, Mansfield AS, Adjei AA. Current diagnosis and management of small-cell lung cancer. Mayo Clin Proc. 2019.

73. Horn L, Mansfield AS, Szczesna A, Havel L, Krzakowski M, Hochmair MJ, et al. First-line atezolizumab plus chemotherapy in extensive-stage small-cell lung cancer. N Engl J Med. 2018.

74. Goldman JW, Dvorkin M, Chen Y, Reinmuth N, Hotta K, Trukhin D, et al. Durvalumab, with or without tremelimumab, plus platinum-etoposide versus platinum-etoposide alone in first-line treatment of extensive-stage small-cell lung cancer (CASPIAN): updated results from a randomised, controlled, openlabel, phase 3 trial. Lancet Oncol. 2021;22(1).

75. Paz-Ares L, Dvorkin M, Chen Y, Reinmuth N, Hotta K, Trukhin D, et al. Durvalumab plus platinumetoposide versus platinum-etoposide in first-line treatment of extensive-stage small-cell lung cancer (CASPIAN): a randomised, controlled, open-label, phase 3 trial. Lancet. 2019;394(10212).

76. Ready N, Farago AF, de Braud F, Atmaca A, Hellmann MD, Schneider JG, et al. Third-line nivolumab monotherapy in recurrent SCLC: CheckMate 032. J Thorac Oncol. 2019;14(2).

77. Vijayvergia N, Dasari A, Ross EA, Dotan E, Halperin DM, Astsaturov IA, et al. Pembrolizumab (P) monotherapy in patients with previously treated metastatic high grade neuroendocrine neoplasms (HG-NENs). J Clin Oncol. 2018;

A prospective phase II study, examining the safety and efficacy of immunotherapy with PD-1 inhibitor monotherapy in highgrade NENs.

78. Fottner C, Apostolidis L, Ferrata M, Krug S, Michl P, Schad A, et al. A phase II, open label, multicenter trial of avelumab in patients with advanced, metastatic high-grade neuroendocrine carcinomas NEC G3 (WHO 2010) progressive after first-line chemotherapy (AVENEC). J Clin Oncol. 2019.

79. Patel SP, Othus M, Chae YK, Giles FJ, Hansel DE, Singh $P P$, et al. A phase ii basket trial of dual anti-CTLA- 4 and anti-PD-1 blockade in rare tumors (DART SWOG 1609) in patients with nonpancreatic neuroendocrine tumors. Clin Cancer Res. 2020.

80. Klein O, Kee D, Markman B, Michael M, Underhill C, Carlino MS, et al. Immunotherapy of ipilimumab and nivolumab in patients with advanced neuroendocrine tumors: a subgroup analysis of the CA209-538 clinical trial for rare cancers. Clin Cancer Res. 2020.

81. Yao JC, Strosberg J, Fazio N, Pavel ME, Bergsland E, Ruszniewski P, et al. Spartalizumab in metastatic, well/poorly-differentiated neuroendocrine neoplasms. Endocr Relat Cancer. 2021; Accepted m.

82. Tiacci E, Park JH, De Carolis L, Chung SS, Broccoli A, Scott S, et al. Targeting mutant BRAF in relapsed or refractory hairy-cell leukemia. N Engl J Med. 2015.

83. Robert C, Grob JJ, Stroyakovskiy D, Karaszewska B, Hauschild A, Levchenko E, et al. Five-year outcomes with dabrafenib plus trametinib in metastatic melanoma. N Engl J Med. 2019.

84. Planchard D, Kim TM, Mazieres J, Quoix E, Riely G, Barlesi F, et al. Dabrafenib in patients with BRAFV600E-positive advanced non-small-cell lung cancer: a single-arm, multicentre, open-label, phase 2 trial. Lancet Oncol. 2016.

85. Corcoran RB, Atreya CE, Falchook GS, Kwak EL, Ryan DP, Bendell JC, et al. Combined BRAF and MEK inhibition with dabrafenib and trametinib in BRAF V600Mutant colorectal cancer. In: Journal of Clinical Oncology; 2015.

86. Barras D, Missiaglia E, Wirapati P, Sieber OM, Jorissen $\mathrm{RN}$, Love C, et al. BRAF V600E mutant colorectal cancer subtypes based on gene expression. Clin Cancer Res. 2017.

87. Klempner SJ, Gershenhorn B, Tran P, Lee TK, Erlander MG, Gowen K, et al. BRAFV600E mutations in highgrade colorectal neuroendocrine tumors may predict responsiveness to BRAF-MEK combination therapy. Cancer Discov. 2016.

88. Idrees K, Padmanabhan C, Liu E, Guo Y, Gonzalez RS, Berlin J, et al. Frequent BRAF mutations suggest a novel oncogenic driver in colonic neuroendocrine carcinoma. J Surg Oncol. 2018.

89. Capdevila J, Arques O, Mora JRH, Matito J, Caratu G, Mancuso FM, et al. Epigenetic EGFR gene repression confers sensitivity to therapeutic BRAFV600E blockade in colon neuroendocrine carcinomas. Clin Cancer Res. 2020;

A multi-omic analysis of colon-NEC, demonstrating that V600E BRAF-mutant colon-NEC may benefit from anti-BRAF monotherapy and the importance of EGFR status for the innate sensitivity and acquired resistance.

90. Sugiyama K, Shiraishi K, Sato M, Nishibori R, Nozawa K, Kitagawa C. Salvage chemotherapy by FOLFIRI regimen for poorly differentiated gastrointestinal neuroendocrine carcinoma. J Gastrointest Cancer. 2020.

\section{Publisher's note}

Springer Nature remains neutral with regard to jurisdictional claims in published maps and institutional affiliations. 